\title{
Correction to: An updated introduction to electroencephalogram- based brain monitoring duringintended general anesthesia
}

\author{
Darren F. Hight, PhD - Heiko A. Kaiser, MD • Jamie W. Sleigh, MBChB • \\ Michael S. Avidan, MBBCh (D)
}

Published online: 11 January 2021

(C) Canadian Anesthesiologists' Society 2021

\section{Correction to:}

Can J Anesth/J Can Anesth

https://doi.org/10.1007/s12630-020-01820-3

This article was updated to correct Heiko A. Kaiser's name. It appeared incorrectly as Heiko K. Kaiser.
Publisher's Note Springer Nature remains neutral with regard to jurisdictional claims in published maps and institutional affiliations.

The original article can be found online at https://doi.org/10.1007/ s12630-020-01820-3.

D. F. Hight, $\mathrm{PhD}$ - H. A. Kaiser, MD

Department of Anaesthesiology and Pain Medicine, Bern University Hospital, University of Bern, Bern, Switzerland

J. W. Sleigh, MBChB

Department of Anaesthesiology, University of Auckland,

Auckland, New Zealand

\section{S. Avidan, MBBCh $(\bowtie)$}

Department of Anesthesiology, Washington University School of Medicine, 660 South Euclid Avenue, Campus Box 8054, St. Louis, MO, USA

e-mail: avidanm@wustl.edu 